\title{
SINTESIS NANOKOMPOSIT Nata de coco/TiO $/$ /Ag DAN EFEKTIVITASNYA SEBAGAI ANTIBAKTERI TERHADAP BAKTERI Escherichia coli dan Staphylococcus aureus
}

\author{
Heriyanto Tinentang ${ }^{1}$, Henry F. Aritonang ${ }^{1}$, Harry S.J Koleangan ${ }^{1}$ \\ ${ }^{1}$ Program Studi Kimia, Fakultas Matematika dan Ilmu Pengetahuan Alam Universitas Samratulangi Manado \\ henryaritonang@unsrat.ac.id
}

\begin{abstract}
ABSTRAK
Telah dilakukan penelitian tentang kemampuan aktivitas anti bakteri untuk bakteri Staphylococcus aureus (gram positif) dan Escherichia coli (gram negatif) dengan menggunakan nanokomposit nata de $\mathrm{coco} / \mathrm{TiO}_{2}$, nata de coco/Ag, dan nata de coco/ $/ \mathrm{TiO}_{2} / \mathrm{Ag}$ dengan variasi konsentrasi $\mathrm{Ag} 0,5 \mathrm{M} ; 0,6 \mathrm{M} ; 0,7 \mathrm{M} ; 0,8 \mathrm{M}$ dan 0,9 M menggunakan metode reduksi kimia. Nanopartikel tersebut dikarakterisasi menggunakan $X$-Ray Diffractometry (XRD), scanning electron microscopy-energy dispersive X-ray spectroscopy (SEM-EDS) dan anti bakteri. Untuk uji aktivitas antibakteri menggunakan metode kertas cakram dan dilakukan sebanyak dua kali ulangan untuk tiap-tiap sampel dan bakteri yang diuji. Hasil penelitian menunjukan, aktivitas anti bakteri nanokomposit yang paling baik dalam menghambat pertumbuhan bakteri adalah nanokomposit Nata de coco/TiO $/$ /Ag mampu menghambat pertumbuhan bakteri Escherichia coli dan Staphylococcus aureus, namun nanokomposit tersebut lebih efektif menghambat pertumbuhan bakteri Escherichia coli.
\end{abstract}

Kata kunci: nanopartikel, Nata de coco, $\mathrm{TiO}_{2}$, Antibakteri.

\section{ABSRACT}

Research on the ability of anti-bacterial activity for Staphylococcus aureus (gram positive) and Escherichia coli (gram negative) bacteria using nata de coco / nanocomposites TiO2, nata de coco / Ag, and nata de coco / TiO2 / Ag with variations of $\mathrm{Ag} \mathrm{0,5} \mathrm{M;0.6} \mathrm{M;} \mathrm{0.7} \mathrm{M;} \mathrm{0.8} \mathrm{M} \mathrm{and} \mathrm{0.9} \mathrm{M} \mathrm{using} \mathrm{the} \mathrm{chemical} \mathrm{reduction} \mathrm{method.}$ Nanoparticles were characterized using $X$-Ray Diffractometry (XRD), scanning electron microscopy-energy dispersive $X$-ray spctroscopy (SEM-EDS) and anti-bacterial actvity. Test the antibacterial activity using the paper disc method and repeated two times for each sample and bacteria tested. The results showed that the good anti-bacterial activity of nanocomposites in inhibiting bacterial growth was nanocomposite nata de coco $/ \mathrm{TiO}_{2} / \mathrm{Ag}$ able to inhibit the growth of Escherichia coli and $\mathrm{S}$. aureus, but the nanocomposite is more effective in inhibiting the growth of Escherichia coli bacteria.

Keywords: nanoparticles, Nata de coco, $\mathrm{TiO}_{2}$, Antibacterial.

\section{PENDAHULUAN}

Dewasa ini, peran nanoteknologi begitu penting dalam pengembangan ilmu pengetahuan dan teknologi untuk kesejahteraan kehidupan manusia. Nanoteknologi telah banyak menarik perhatian tidak hanya para ilmuwan dan peneliti, melainkan juga para pengusaha karena diyakini bahwa nanoteknologi dapat diaplikasikan pada berbagai bidang. Nanopartikel yang menghasilkan partikel berukuran nano atau disebut nanopartikel telah populer dan semakin pesat perkembangannya sejak awal tahun 2000 . Hal ini disebabkan oleh manfaat dan dampaknya yang sangat luas dalam kehidupan manusia. Manfaat dan aplikasi nanopartikel saat ini telah berkembang di berbagai bidang, diantaranya yaitu di bidang lingkungan, biomedis, perawatan kesehatan, pertanian dan pangan, tekstil, industri, elektronika, serta energi (Tsuzuki, 2009). Nanopartikel yang dihasilkan tersebut, baik dalam bentuk logam (atau paduan beberapa logam) maupun dalam bentuk komposit yang telah digabung dengan material nonlogam, seperti nata de coco (Li dkk., 2010).

Salah satu nanopartikel terpenting yang dimiliki dan menarik perhatian besar karena sifat uniknya adalah titaniumdioksida $\left(\mathrm{TiO}_{2}\right)$. Serbuk $\mathrm{TiO}_{2}$ memiliki sifat optik yang menarik,sifat dielektrik, dan katalitik, yang mengarah ke industri aplikasi seperti pigmen, pengisi, katalis pendukung, danfotokatalis (Tian dkk., 2013; Chong dkk., 2010; Bumajdad A dkk., 2014; Liou and Chang, 2012).Selain itu, nanopartikel $\mathrm{TiO}_{2}$ juga efektif sebagai antibakteri (Duymaza dkk., 2016; Ahmad \& Sardar, 2013). Selain dalam bentuk tunggal, 
nanopartikel $\mathrm{TiO}_{2}$ juga digabung dengan logam lain dalam bentuk nanokomposit, seperti nanopartikel $\mathrm{Ag}$ dan ternyata efektivitasnya sebagai antibakteri relatif lebih baik dibanding bila $\mathrm{TiO}_{2}$ dalam bentuk tunggal (Barudin dkk., 2019). Nanokomposit paduan logam atau logam/oksida logam, khususnya nanokomposit $\mathrm{TiO}_{2} / \mathrm{Ag}$ kebanyakan dilaporkan disintesis melalui metode sol-gel (Santos dkk.,2015; Ubonchonlakate dkk., 2011; Silva dkk., 2017) hidrotermal (Castro dkk., 2011; Sarteep dkk. 2016) dan kopresipitasi. Sementara itu, untuk mensintesis nanopartikel logam, khususnya $\mathrm{Ag}$ lebih banyak dilaporkan disintesis dengan metode reduksi kimia menggunakan reduktor dan penstabil dari bahan kimia, diantaranya, penstabil natrium sitrat (Quintero-Quiroz dkk., 2019) dan natrium dodekil sulfat (Song dkk., 2009).

Khalid dkk. (2017) telah mensintesis nanokomposit Nata de coco/TiO $\mathrm{Tin}_{2}$ untuk digunakan sebagai regenerasi jaringan. Penelitian tersebut melaporkan bahwa nanokomposit menunjukkan efektivitasnya sebagai antibakteri, baik bakteri gram negatif yaitu bakteri Escherichia coli (E. coli) maupun positif, Staphylococcus aureus (S. Aureus). Berdasarkan penelitian ini, peneliti mencoba untuk mensintesis nanokomposit Nata de coco $/ \mathrm{TiO}_{2} / \mathrm{Ag}$ dan dikarakterisasi dengan $X$ Ray Diffractometry (XRD). Tujuan untuk mensintesis nanokomposit nata de cocol $\mathrm{TiO}_{2} / \mathrm{Ag}$ dan membuktikan aktivitas antibakteri pada E. coli maupun $S$. Aureus.

\section{BAHAN DAN METODE}

Beberapa bahan kimia yang digunakan dalam penelitian adalah titan oksida, perak nitrat nitrat, natrium boron tetrahidrat, etanol, asam asetat glasial diperoleh dari Merck (Damstadt, Germany), sedangkan nata de coco, air kelapa diperoleh dari pasar lokal di Manado. Tablet cyprofoxasin, bakteri Staphylococcus aureus dan Eschericia coli, larutan Mc. Farland diperoleh dari Laboratorium Mikrobiologi, Prodi Farmasi, FMIPA Unsrat.

\section{Pembuatan nata de coco}

Pembuatan nata de coco mengikuti prosedur Radiman dkk. (2008). Sebanyak 5 L air kelapa tua disaring dengan kain kasa, dimasak hingga mendidih. Kemudian ditambahkan $500 \mathrm{~g}$ gula putih, $25 \mathrm{~g}$ urea dan
$30 \mathrm{~mL}$ asam asetat glasial, sambil diaduk. Sebanyak $300 \mathrm{~mL}$ larutan ini dituangkan ke dalam nampan plastik, ditutup dan dibiarkan hingga benar-benar dingin. Setelah dingin, Acetobacter xylinumm ditambahkan sebanyak $10 \%$ volume media, yakni sekitar $30 \mathrm{~mL}$ bakteri untuk $300 \mathrm{~mL}$ larutan media kemudian dibiarkan selama 6 hari. Gel nata de coco yang dihasilkan dicuci dengan air panas selama 15 menit, direndam dalam larutan $10 \mathrm{~g} \mathrm{NaOH}$ dalam $1 \mathrm{~L}$ larutan $(1 \%(\mathrm{~b} / \mathrm{v}))$ selama $24 \mathrm{jam}$. Kemudian gel nata de coco ini direndam lagi dengan $10 \mathrm{ml}$ larutan asam asetat glasial dalam 1 L larutan $(1 \%(\mathrm{v} / \mathrm{v}))$ selama 24 jam dan dicuci dengan aquades hingga $\mathrm{pH}$ netral. Selanjutnya gel nata de coco disimpan dalam larutan $200 \mathrm{~mL}$ etanol dalam $1 \mathrm{~L}$ larutan $(20 \%$ $(\mathrm{v} / \mathrm{v}))$ di dalam lemari es. Untuk membuat membran nata de coco yang tipis digunakan alat pres dari batu timbangan. Nata de coco dipotong dengan ukuran $3 \mathrm{~cm} \times 3 \mathrm{~cm}$ dan dikurangi kadar airnya dengan cara dihimpitkan diantara 2 buah batu timbangan selama 15 menit untuk selanjutnya digunakan pada sintesis nanokomposit.

\section{Sintesis nanokomposit Nata de coco $\mathrm{TiO}_{2} / \mathrm{Ag}$ (Song dkk., 2009)}

Sebanyak 0,1 g $\mathrm{TiO}_{2}$ dilarutkan ke dalam $50 \mathrm{~mL}$ akuades dan diaduk dengan bantuan stirer selama 1 jam. Kemudian, ke dalam larutan tersebut dimasukkan sebanyak $10 \mathrm{~mL}$ larutan $\mathrm{AgNO}_{3}$ 0,5 $\mathrm{M}$ dan diaduk kembali dengan bantuan stirer selama 1 jam. Ke dalam campuran tersebut dimasukkan nata de coco dan bersamaan dengan penambahan kembali akuades sebanyak $10 \mathrm{~mL}$ dan diikuti dengan penambahan $20 \mathrm{~mL}$ larutan $\mathrm{NaBH}_{4}$ $0,05 \mathrm{M}$ dan diaduk kembali selama 2 jam. Selanjutnya, Nata de coco yang telah mengandung nanopartikel $\mathrm{TiO}_{2} / \mathrm{Ag}$ (nata de coco $/ \mathrm{TiO}_{2} / \mathrm{Ag}$ ) dikeluarkan dari larutannya dan komposit yang dihasilkan tersebut dihimpitkan diantara 2 buah batu timbangan selama 15 menit untuk mengurangi kadar airnya dan dikering-anginkan selama 6 hari. Nanokomposit nata de coco/TiO $/ \mathrm{Ag}$ yang telah kering siap untuk dianalisis dengan XRD, SEM-EDS dan dianalisis efektivitasnya sebagai antibakteri.Sebagai kontrol, disintesis juga nanokomposit nata de coco/TiO $\mathrm{Tan}_{2}$ nata de coco/Ag. Dengan cara yang sama, dilakukan juga untuk variasi konsentrasi $\mathrm{AgNO}_{3}$ yaitu $0,6 \mathrm{M} ; 0,7 \mathrm{M} ; 0,8 \mathrm{M}$, dan 0,9M. 


\section{$X$-ray diffraction (XRD)}

Pola XRD dicatat pada difraktometer sinar-X (PW1710, Philips), menggunakan radiasi $\mathrm{Cu} \mathrm{K \alpha}(\lambda=0.154056 \mathrm{~nm})$ pada $40 \mathrm{kV}$ dan $30 \mathrm{~mA}$. Sudut difraksi berkisar antara $25^{\circ}$ sampai $80^{\circ}$. Ukuran kristalit nanopartikel nata de coco $/ \mathrm{TiO}_{2} / \mathrm{Ag}$ dihitung berdasarkan pengukuran difraksi sinar-X. Ukuran kristal dihitung dari FWHM puncaknya dengan menggunakan rumus Scherrer (Monshi dkk., 2012)

$$
L=\frac{k \lambda}{\beta \cos \theta}, \ldots \ldots \ldots \ldots
$$

dimana $L$ adalah ukuran kristal rata-rata partikel $\mathrm{TiO}_{2} / \mathrm{Ag}, K$ adalah konstanta yang bernilai $0,9, \lambda$ adalah panjang gelombang sinar$\mathrm{X}, \beta$ adalah (FWHM) dalam radian, dan $\theta$ adalah sudut difraksi.

\section{Pembuatan media tumbuh dan aterilisasi alat}

Sebanyak 8,2 g nutrient agar (NA) dilarutkan dalam $300 \mathrm{~mL}$ akuades kemudian larutan NA yang telah dibuat dan 14 cawan petri maupun alat-alat gelas yang digunakan dalam pengujian dimasukkan ke dalam autoclave selama 30 menit untuk disterilisasi.

\section{Pembuatan larutan Mc Farland}

Sebanyak $\quad 0,5 \quad \mathrm{~mL} \quad \mathrm{BaCl}_{2} \quad 1,75 \quad \%$ (dibuat dengan cara melarutkan $1.75 \mathrm{~g} \mathrm{BaCl}_{2}$ ke dalam $100 \mathrm{~mL}$ akuades) ditambahkan dengan 9,5 $\mathrm{mL} \mathrm{H}_{2} \mathrm{SO}_{4} \quad 1 \%$ (dibuat dengan cara $1 \mathrm{~mL} \quad \mathrm{H}_{2} \mathrm{SO}_{4}$ pekat ditambahkan aquades sampai $100 \mathrm{~mL}$ ) sehingga volume larutan mencapai $10 \mathrm{~mL}$. Kemudian, larutan dipindahkan ke dalam tabung reaksi dan divortex dan dilihat kekeruhannya.

\section{Pembuatan bakteri uji}

Bakteri diencerkan dengan mencampurkan masing-masing 1 ose suspensi bakteri Staphylococcus aureus dan Escherichia coli ke dalam tabung reaksi yang telah berisi 5 $\mathrm{mL}$ larutan $\mathrm{NaCl} \quad 0,9 \quad \%$. Kemudian dihomogenkan menggunakan vortex dan kekeruhannya dibandingkan dengan kekeruhan 0,5 McFarland hingga kekeruhan larutan bakteri harus sama dengan kekeruhan larutan 0,5 Mc Farland. Jika kekeruhan larutan belum sama, maka ke dalam larutan bakteri ditambahkan lagi 1 ose suspensi bakteri hingga kekeruhan larutan bakteri sama dengan kekeruhan larutan 0,5 Mc Farland, sehingga jumlah bakteri memenuhi standarisasi untuk uji kepekaan yaitu: $10^{5}-10^{8} / \mathrm{ml}$.

\section{Uji daya hambat bakteri (Eko, 2013)}

Dimasukkan sebanyak $20 \mathrm{~mL}$ larutan nutrient Agar ke dalam cawan petri kemudian didiamkan selama 15 menit sampai larutan nutrient Agar mengeras. Kemudian sebanyak $0,1 \mathrm{~mL}$ larutan bakteri yang telah distandarisasi tadi, dioleskan pada media tumbuh nutrient Agar. Setelah itu, diletakkan kontrol negatif, kontrol positif, dan sampel yang telah disiapkan (2 ulangan). Media yang telah dibuat, diinkubasi ke dalam inkubator dengan suhu $37^{\circ} \mathrm{C}$ selama 24 jam, dan diukur pada keesokan harinya dengan diameter zona bening (clear zone) yang terbentuk dengan menggunakan jangka sorong (Eko, 2013).

\section{HASIL DAN PEMBAHASAN}

\section{Pembuatan nata de coco}

Pembuatan nata de coco (bacterial selulose) sebagai capping agent atau agen penstabil untuk pembuatan sintesis nanopartikel.Capping agen berperan dalam membuat partikel menjadi berukuran nano. Bakteri Acetobacter xylinum berperan dalam mensintesis nata de coco sedangkan air kelapa menjadi media tumbuh atau sumber pangan bakteri Acetobacter xylinum dari nata de coco. Dalam pembuatan tersebut ditambahkan amonium sulfat dan glukosa yang merupakan sumber karbohidrat dan nitrogen untuk metabolisme dari bakteri. Penambahan asam asetat glacial bertujuan untuk terciptanya suasana asam agar bakteri dapat tumbuh dengan baik(Iguchi dkk.,2000).

Lapisan selulosa tebal pada permukaan media dihasilkan dari bakteri Acetobacter xylinum. Sintesis polisakarida oleh bakteri Acetobacter xylinum dalam pembuatan nata de coco berasal dari gula sederhana baik sukrosa, maltosa, maupun glukosa pada umumnya sama dengan mensintesis pati dari glukosa. Oleh bakteri Acetobacter xylinum glukosa yang ada dalam air kelapa dikonversi ke dalam bentuk fruktosa dan glukosa dikarenakan adanya enzim sukrase yaitu bakteri yang dapat mengubah fruktosa dan glukosa (Radiman \& Yuliani, 2008). Dalam proses sintesis nanokomposit, pencucian dengan air panas 
pada gel nata de coco bertujuan untuk menghilangkan bakteri yang masih menempel pada gel nata de coco. Perendaman selama 24 jam dengan $\mathrm{NaOH}$ untuk menciptakan suasana basah sehingga $\mathrm{pH}$ menjadi naik dan bakteri Acetobacter xylinum benar-benar hilang dari permukaan gel nata de coco. Selanjutnya direndam lagi selama 24 jam dengan asam asetat glasial bertujuan untuk menurunkan $\mathrm{pH}$, dan pencucian dengan aquades bertujuan untuk menetralkan gel nata de coco. Selanjutnya gel nata de coco yang telah dihasilkan dipotong dengan ukuran $3 \mathrm{~cm} \times 3 \mathrm{~cm}$ dan dihimpitkan dengan dua buah batu timbangan selama 15 menit untuk mengurangi kadar air yang masih terdapat dalam rongga nata de coco agar efektif dalam menyerap nanopartikel $\mathrm{TiO}_{2}$ dan Ag.

\section{Sintesis nanokomposit Nata de coco/ $/ \mathrm{TiO}_{2} / \mathrm{Ag}$}

Membran nanokomposit nata de coco $\mathrm{TiO}_{2} / \mathrm{Ag}$ disintesis dengan cara merendam nata de coco kedalam larutan $\mathrm{TiO}_{2}$ dan $\mathrm{AgNO}_{3}$. Secara insitu proses ini dilakukan dengan tujuan agar nanoprtikel $\mathrm{TiO}_{2}$ dan Agterdeposisi dengan baik. Penambahan $\mathrm{NaBH}_{4}$ kedalam larutan, bertujuan untuk mereduksi $\mathrm{AgNO}_{3}$ sehingga terbentuk Ag. Dengan menggunakan stirrer proses deposisi tersebut dilakukan agar nanopartikel yang terbentuk terdistribusi secara merata kedalam serat nata de coco. Sebelum dan setelah proses deposis, perubahan warna yang terjadi pada membran nata de coco menunjukan bahwa telah terdeposisinya $\mathrm{TiO}_{2}$ dan Ag. Secara visual perbedaan morfologi dari membran nanokomposit, sebelum dan setelah terdeposisinya masing-masing nanopartikel $\mathrm{TiO}_{2}$ dan $\mathrm{Ag}$ dari hasil sintesis, disajikan pada Gambar 1 berikut.

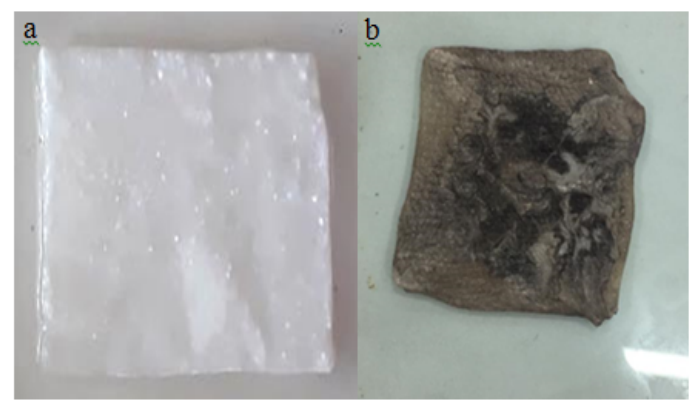

Gambar 1. Perbedaan morfologi membran nata de coco sebelum dan setelah deposisi, (a) nanokomposit nata de coco/ $/ \mathrm{TiO}_{2}$, (b) Nata de coco $\mathrm{TiO}_{2} / \mathrm{Ag}$

\section{Karakterisasi dengan X-ray diffractometry (XRD)}

Untuk mengetahui telah terbentuknya partikel-partikel $\mathrm{TiO}_{2}$ dan $\mathrm{Ag}$ dari sumber prekursornya didalam membran nata de coco, maka dianalisis dengan XRD. Pada difraktogram akan muncul pola difraksi dengan adanyya puncak-puncak pada daerah $2 \theta$ yang karakteristik deengan dengan partikel tersebut seperti tersaji pada Gambar 2 berikut.

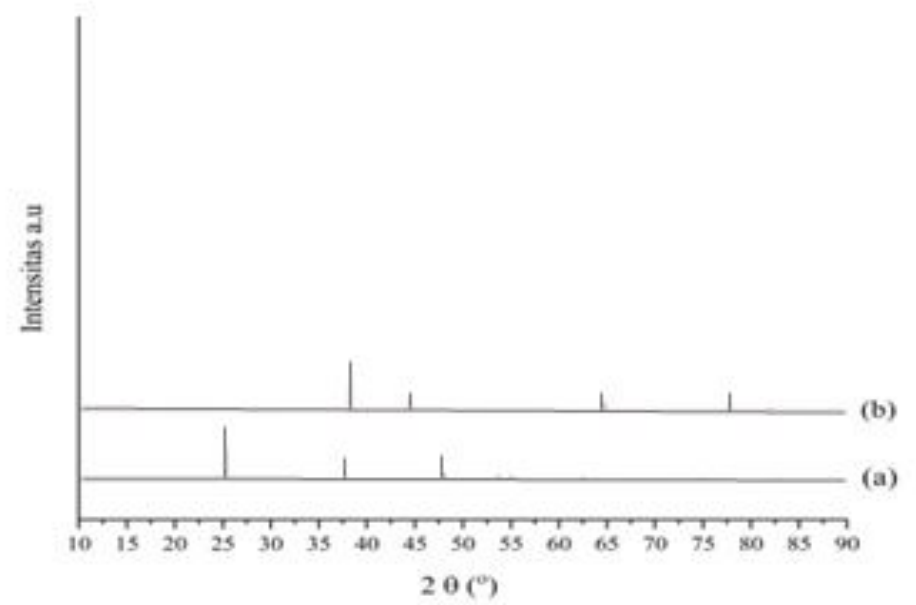

Gambar 2. Difraktogram (a) Standar $\mathrm{TiO}_{2}$, dan (b) standar $\mathrm{Ag}$ 
Pola difraksi sampel membran nanokomposit telah dibandingkan dengan pola difraksi standar untuk partikel-partikel $\mathrm{TiO}_{2}$ dan Ag. Dalam penelitian ini, sebagai pembanding menggunakan standar dari Inorganic Crystal Structur Database (ICSD).
Berdasarkan data dari ICSD tersebut, daerah $2 \theta$ untuk $\mathrm{TiO}_{2}$ standar yaitu $25,28^{\circ} ; 36,96^{\circ} 37,70^{\circ}$; $38,54^{\mathrm{o}} ; 47,98^{\mathrm{o}} ; 53,76^{\circ} ; 55,00^{\circ} ; 62,18^{\mathrm{o}} ; 62,56^{\mathrm{o}}$; $62,74^{\circ} ; 62,8^{\circ} ; 68,50^{\circ}$, sedangkan untuk $\mathrm{Ag}$ standar yaitu $38,08^{\circ} ; 44,56^{\circ} ; 64,76^{\circ} ; 64,76^{\circ}$
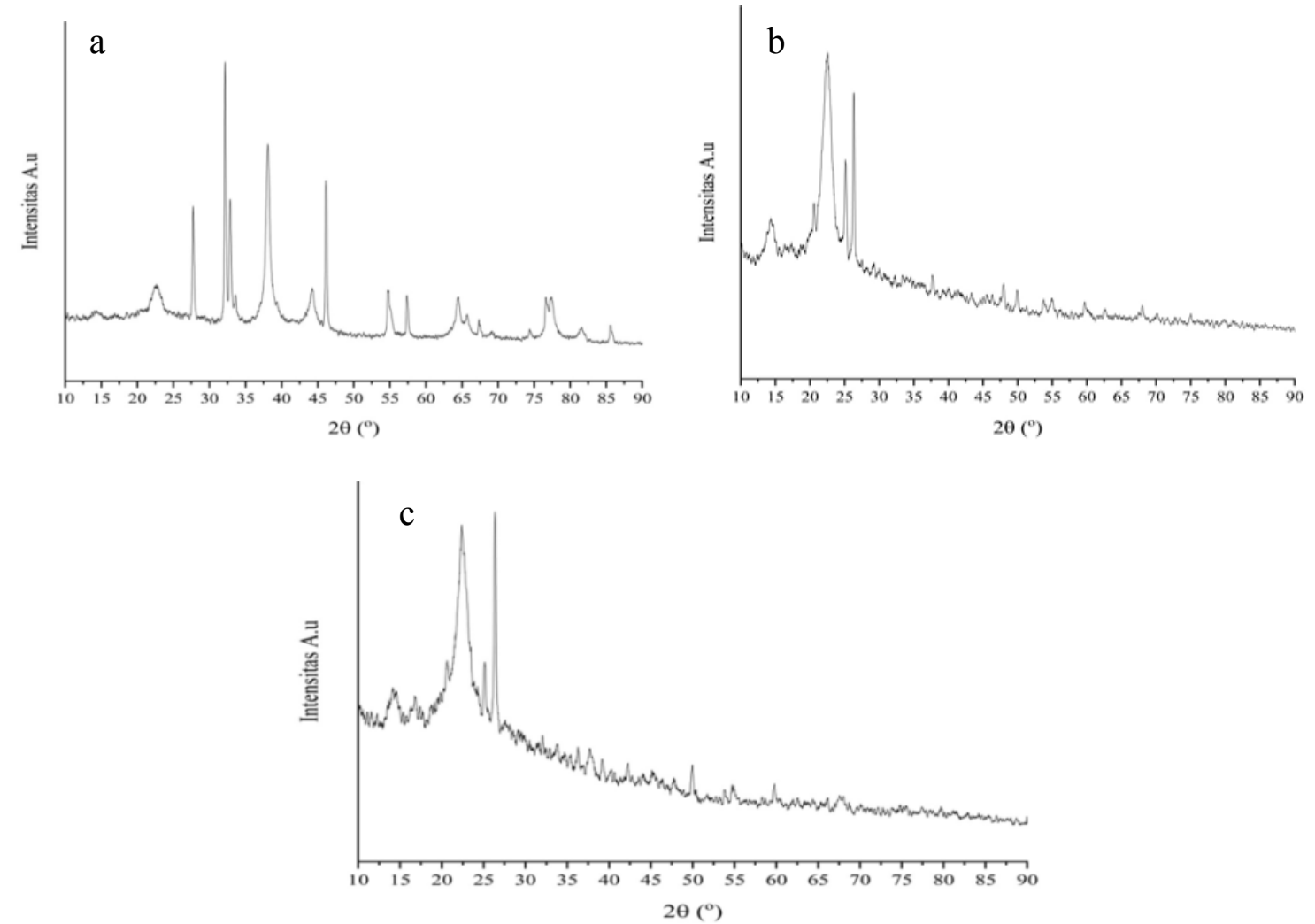

Gambar 3. Difraktogram sampel nanokomposit (a) Nata de coco/Ag, (b) Nata de coco/ $\mathrm{TiO}_{2}$ (c) Nata de coco $\mathrm{TiO}_{2} / \mathrm{Ag}(0,5 \mathrm{M})$

Berdasarkan difraktogram tersebut puncak-puncak daerah $2 \theta$ sampel Nata de coco/Ag yaitu $14,11^{\circ} ; 22,33^{\circ} ; 27,71^{\circ} ; 32,13^{\circ}$; $32,9^{\circ} ; 38,06^{\circ} ; 46,12^{\circ} ; 54,68^{\circ} ; 57,36^{\circ} ; 64,48^{\circ}$. Sedangkan untuk Nata de coco/TiO 2 yaitu

$14,32^{\circ} ; 22,49^{\circ} ; 25,14^{\circ} ; 26,33^{\circ} ; 47,85^{\circ} ; 49,89^{\circ}$; $67,84^{\circ}$. Dan untuk Nata de coco/ $/ \mathrm{TiO}_{2} / \mathrm{Ag}$ berada pada posisi puncak $2 \theta$ yaitu $25,16^{\circ}$; $26,37^{\circ}$

$67,73^{\circ}$.

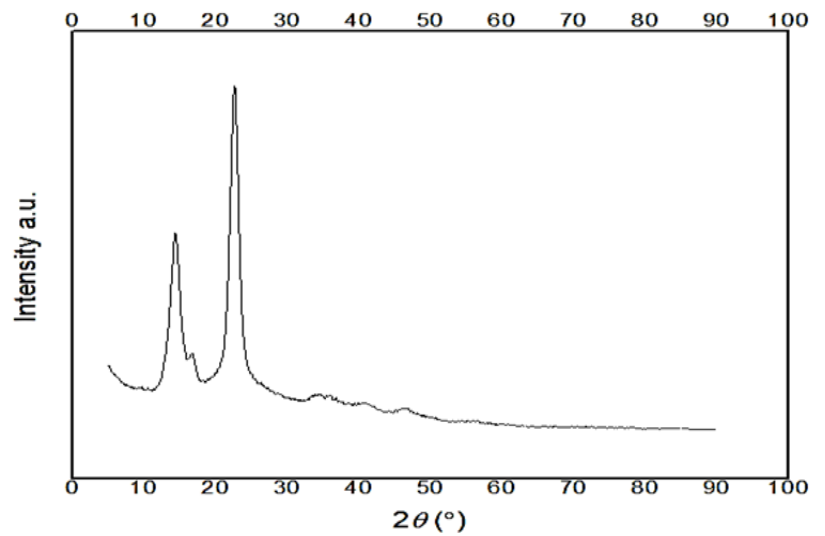

Gambar 4. Difraktogram nata de coco (Aritonang dkk., 2017) 
Selain puncak-puncak nanopartikel $\mathrm{TiO}_{2}$ daan Ag pada difraktogram nanokomposit juga muncul puncak nata de coco. Menurut Aritonang dkk. (2017), puncak nata de coco berada pada daerah $2 \theta=14^{\circ}, 17^{\circ}$, dan $22^{\circ}$ seperti yang tampak pada (Gambar 4). Berdasarkan difraktogram nata de coco, tampak bahwa intensitas puncak-puncak nata de coco pada membran nanokomposit, khususnya pada daerah $2 \theta=14^{\circ}$ dan $17^{\circ}$ semakin rendah bahkan hampir hilang. Ini disebabkan karena permukaan nata de coco telah ditutupi oleh nanopartikel $\mathrm{TiO}_{2}$ dan Ag.
Uji aktivitas antibakteri menggunakan nanokomposit nata de coco/ $/ \mathrm{TiO}_{2} / \mathrm{Ag}$

Sampel nanokomposit nata de coco/ $\mathrm{TiO}_{2} / \mathrm{Ag}$ yang dihasilkan dalam penelitian ini diuji aktivitas antibakterinya, baik bakteri gram-negatif (Escherichia coli) maupun gram-positif (Staphylococcus aureus) serta analisis efektivitasnya. Uji aktivitas antibakteri diukur berdasarkan daya hambat pertumbuhan bakteri (Bonang, 1992). Data daya hambat pertumbuhan bakteri tersaji pada Gambar 5 .

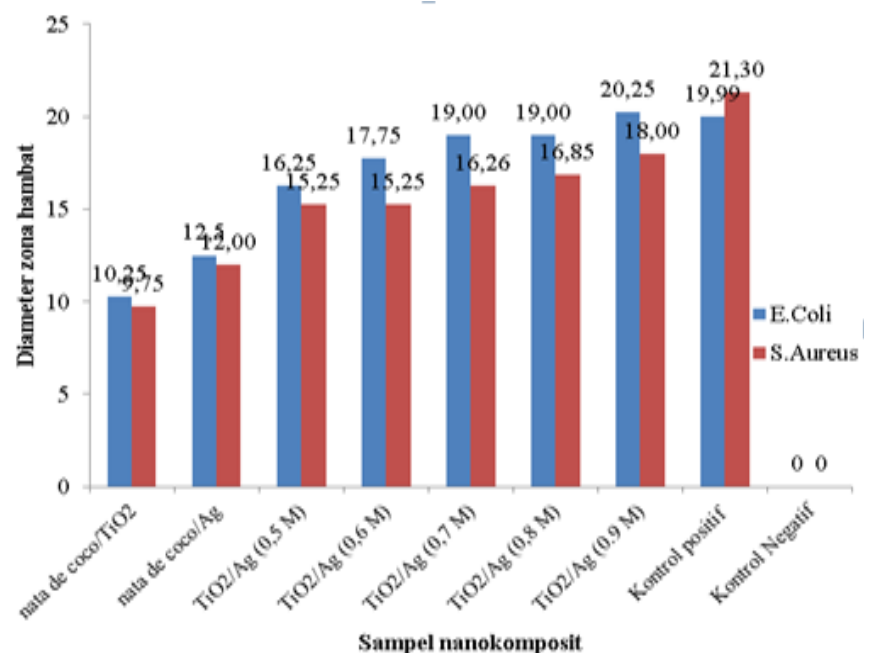

Gambar 5. Aktivitas antibakteri dari membran nanokomposit terhadap bakteri Escherichia coli dan Staphylococcus aureus

Gambar 5 menunjukkan bahwa nanopartikel $\mathrm{TiO}_{2}$ dan $\mathrm{Ag}$ relatif lebih efektif dalam menghambat pertumbuhan bakteri Escherichia coli dibandingkan bakteri Staphylococcus aureus. Dengan variasi konsentrasi Ag yang berbeda-beda terhadap nanokomposit nata de coco/ $/ \mathrm{TiO}_{2} / \mathrm{Ag}$, menunjukkan daya hambat pertumbuhan bakteri yang dihasilkan juga berbeda-beda. Pada saat menggunakan membran nanokomposit nata de coco/ $/ \mathrm{TiO}_{2} / \mathrm{Ag}(\mathrm{Ag}: 0,5$ $\mathrm{M})$, daya hambat rata-rata yang dihasilkan lebih rendah, hal ini disebabkan karena nano partikel logam yang masuk kedalam serat selulosa hanya sedikt karena konsentrasi Ag hanya sebesar $0,5 \mathrm{M}$ sehingga menyebabkan daya hambat dari bakteri lebih rendah, dan akan terus naik daya hambatnya hingga konsentrasi $\mathrm{Ag}$ : 0,9 M. Naiknya daya hambat tersebut karena nanopartikel logam yang masuk dan menempel kesemua bagian seratserat selulosa terdistribusi secara merata sehingga menyebabkan daya hambat dari bakteri lebih tinggi (Mahendra dkk., 2009; Aritonang dkk., 2015; Maneerung dkk., 2007). 

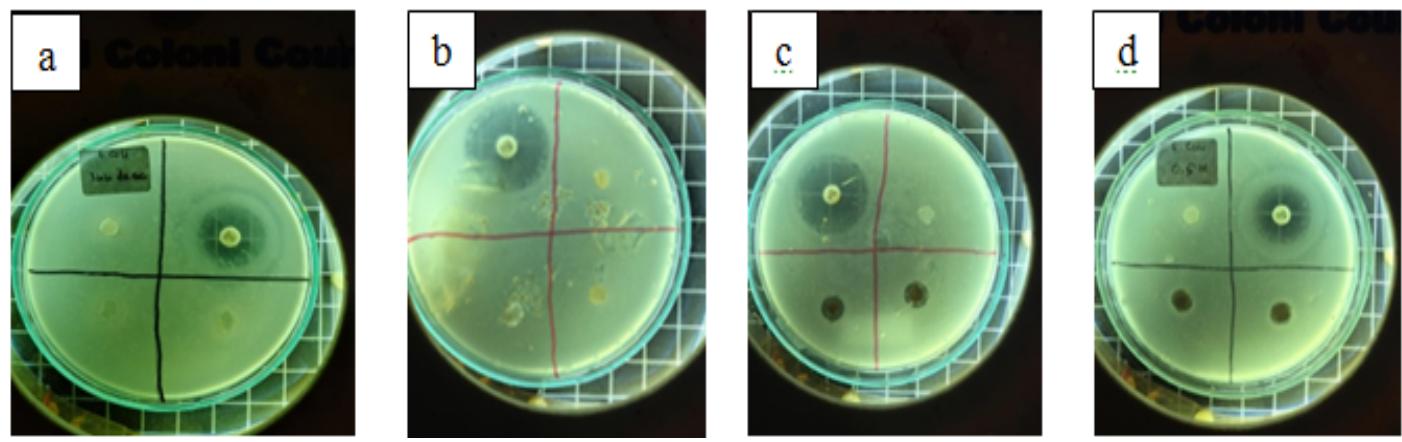

Gambar 6. hasil uji aktivitas antibakteri terhadap bakteri gram negatif (Escherichia coli). (a) Nata de coco (b) Nata de coco/TiO $/$; (c) Nata de coco/Ag (d) $\mathrm{TiO}_{2} / \mathrm{Ag} 0,5 \mathrm{M}$

Jika dibandingkan aktivitas membran nanokomposit terhadap masing-masing kedua bakteri tersebut berdasarkan daya hambatnya menunjukkan kecenderungan yang sama. Ketika dipadukan antara nanopartikel $\mathrm{TiO}_{2}$ dan Ag, maka daya hambatnya selalu diawali lebih rendah dan akan naik terus karena konsentrasi Ag yang terus meningkat. Jadi dapat dikatakan bahwa semakin tinggi konsentrasi Ag maka semakin efektif dalam menghambat pertumbuhan bakteri. Dengan demikian membran nanokomposit nata de coco $\mathrm{TiO}_{2} / \mathrm{Ag}$ ini lebih efektif dalam menghambat pertumbuhan bakteri gram-negatif Escherichia coli.
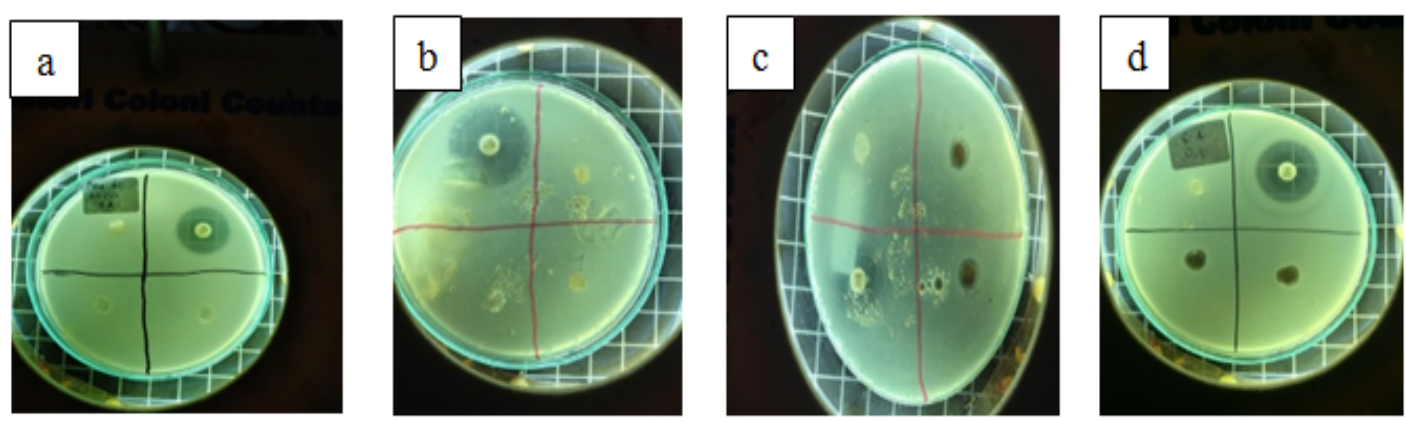

Gambar 7. Hasil uji aktivitas antibakteri terhadap bakteri gram positif (Staphylococcus aureus). (a) Nata de coco (b) Nata de coco/TiO 2 ; (c) Nata de coco/Ag (d) $\mathrm{TiO}_{2} / \mathrm{Ag} 0,5 \mathrm{M}$

\section{KESIMPULAN}

Berdasarkan penelitian yang telah dilakukan dapat disimpulkan bahwa, nanokomposit nata de coco $\mathrm{TiO}_{2} / \mathrm{Ag}$ dapat disintesis melalui proses perendaman nata de coco di dalam larutan yang berisi $\mathrm{TiO}_{2}$ dan $\mathrm{AgNO}_{3}$ dan diikuti dengan penambahan reduktor $\mathrm{NaBH}_{4}$ untuk mereduksi $\mathrm{AgNO}_{3}$ menjadi nanopartikel Ag. Nanokomposit nata de coco $\mathrm{TiO}_{2} / \mathrm{Ag}$ mampu menghambat pertumbuhan bakteri Escherichia coli dan Staphylococcus aureus, namun nanokomposit tersebut lebih efektif menghambat pertumbuhan bakteri Escherichia coli.

\section{DAFTAR PUSTAKA}

Ahmad, R. \& Sardar, M. 2013. $\mathrm{TiO}_{2}$ nanoparticles as an antibacterial agents against E. coli. International Journal of Innovative Research and Science Engenering Technology. 2(8), 35693574.

Aritonang, H.F., Onggo, D. \& Radiman, C.L.2015. Insertion of platinum particles in bacterial cellulose membranes from $\mathrm{PtCl} 4$ and $\mathrm{H}_{2} \mathrm{PtCl}_{6}$ precursors. Macro molecular Symposia. 353(1), 55-61.

Aritonang, H. F., Kamu, V. S., Cipati, C., Onggo, D., Randiman, C. L. 2017. Performance of platinum nanoparticles/multiwalled carbon nanotubes/bacterial cellulose 
composite as anode catalyst for proton exchange membrane fuel cells. Bulletin of Chemical Reaction Engineering \& Catalysis. 12(2), 287-292.

Bumajdad, A., Madkour, M., Abdel-Moneam, Y. \& El-Kemary, M. 2014. Nanostructured mesoporous $\mathrm{Au} / \mathrm{TiO}_{2}$ for photocatalytic degradation of a textile dye: the effect of size similarity of the deposited $\mathrm{Au}$ with that of $\mathrm{TiO}_{2}$ pores. Journal of Materials Science. 49(4), 1743-1754.

Castro, A.L., Nunes, M.R., Carvalho, A.P., Costa, F. M. \& Florêncio, M.H. 2008. "Synthesis of anatase $\mathrm{TiO}_{2}$ nanoparticles with high temperature stability and photocatalytic activity". Solid State Sciences. 10(5), 602-606.

Duymaz, B., Yigit, Z.V., Şeker, M.G. \& Dündar, F. 2016. Antibacterial properties of sol-gel derived $\mathrm{TiO}_{2}$ nanoparticles. Acta Physica Polonica, A. 129(4), 872-874.

Iguchi, M., Yamanaka, S. \& Budhiono, A. 2000. Bacterial Cellulose A Masterpiece Of Nature's Arts. Journal of Material Science. 35(2), 261-270.

Ubonchonlakate, K., Sikong, L. \& Saito, F. 2011. Photocatalytic disinfection of P..aeruginosa bacterial Ag-doped $\mathrm{TiO}_{2}$ film. Procedia Engineering. 32(5), 656-662.

Khalid, A., Ullah, H., Ul-Islam, M., Khan, R., Khan, S., Ahmad, F. \& Wahid, F. 2017. Bacterial cellulose- $\mathrm{TiO}_{2}$ nanocomposites promote healing and tissue regeneration in burn mice model. RSC Advances. 7(75), 4766247668.

Li, Y., Herman, J., Schluesener \& Xu, S. 2010. Gold nanoparticles-based biosensors. Gold Bulletin. 43(1), 29-41.

Liou, J. W. \& Chang, H.H. 2012. Bactericidal effects and mechanisms of visible light-responsive titanium dioxide photocatalysts on pathogenic bacteria." Archivum immunologiae et therapiae experimentalis . 60(4), 267275.

Quintero-Quiroz, C., Natalia Acevedo, N., Zapata-Giraldo, J., Botero, L.E., Quintero, J., Zárate-Triviño, D., Saldarriaga, J. \& Pérez, V.Z. 2019. Optimization of silver nanoparticle synthesis by chemical reduction and evaluation of its antimicrobial and toxic activity. Biomaterials Research. 23(1), 1-15.

Quintero-Quiroz, C., Acevedo, N., ZapataGiraldo, J., Botero, L.E., Quintero, J., Zárate-Triviño, D. \& Pérez, V.Z. 2019. Optimization of silver nanoparticlesynthesis by chemical reduction andevaluation of its antimicrobial and toxicactivity. Biomaterials Research. 23(1), 1-15.

Tian, W.C., Ho, Y.H., Chen, C.H. \& Kuo, C.Y. 2013. Sensing performance of precisely ordered $\mathrm{TiO} 2$ nanowire gas sensors fabricated by electron-beam lithography. Sensors. 13(1), 865-874.

Tsuzuki, T. 2009. Commercial scale production of inorganic nanoparticles. International Journal of Nanotechnology. 6(5), 567-578.

Yang, G., Xie, J., Hong, F., Cao, Z. \& Yang, $X$. 2012. Antimicrobial activity of silver nanoparticle impregnated bacterial cellulose membrane: Effect of fermentation carbon sources of bacterial cellulose. Carbohydrat Polymers. 87(1), 839-845.

Sarteep, Z., Ebrahimian Pirbazari, A. \& Aroon, M.A. 2016. Silver doped $\mathrm{TiO}_{2}$ nanoparticles: preparation, characterization and efficient degradation of 2,4 dichlorophenol under visible light.. Journal of Water and Enviromental Nanotechnology. $1(2)$, 135-144. 